\title{
3-Fluorobenzoate enriched bacterial strain FLB 300 degrades benzoate and all three isomeric monofluorobenzoates
}

\author{
Karl H. Engesser ${ }^{1}{ }^{*}$, Georg Auling ${ }^{2}$, Jürgen Busse ${ }^{2}$, and Hans-J. Knackmuss ${ }^{1}$ \\ I Institut für Mikrobiologie der Universitāt Stuttgart, Azenbergstrasse 1, D-7000 Stuttgart 1, Federal Republic of Germany \\ ${ }^{2}$ Institut für Mikrobiologic der Universität Hannover, Schneiderberg 50, D-3000 Hannover 1, Federal Republic of Germany
}

\begin{abstract}
The bacterial strain FLB 300 was enriched with 3 . fluorobenzoate as sole carbon source. Besides benzoate all isomeric monofluorobenzoates were utilized. Regioselective 1,2-dioxygenation rather than 1,6-dioxygenation yielded 4fluorocatechol and minimized the production of toxic 3fluorocatechol. Degradation of 4-fluorocatechol was mediated by reactions of ortho cleavage pathway activities. Chemotaxonomic and r-RNA data excluded strain FLB300 from a phylogenetically defined genus Pseudomonas and suggested its allocation to the alpha-2 subclass of Proteobacteria in a new genus of the Agrobacteriam-Rhizobium branch.
\end{abstract}

Key words: 3-Fluorobenzoate - 4-Fluorocatechol Orthopathway - Chemotaxonomy - rRNA analysis Quinone pattern analysis - Polyamine pattern analysis Agrobacterium - Rhizobium branch

Fluorosubstituted aromatic compounds are produced by the plastics, agricultural and pharmaceutical industries (Banks 1979, 1982; Filler 1979; Welch 1987; Gajewski et al. 1988). Despite their widespread use general knowledge of the biochemistry and physiology of these compounds is rather limited when compared with chlorinated chemicals.

Fluorobenzoates have frequently been used as model compounds for bacterial metabolism of fluorinated aromatics (Engesser et al. 1980; Harper and Blakley 1971 a-c; Schreiber et al. 1980; Karasevich and Zaitsev 1984; Hug et al. 1988; Engesser and Schulte 1989).

Although the metabolism of 2- and 4-fluorobenzoate has been investigated in greater detail, little information is available on the microbial degradation of 3-fluorobenzoate. This may be due to the fact that the metabolism of 3 fluorobenzoate by benzoate utilizing bacteria gives rise to the accumulation of fluorocatechols as toxic intermediates (Schreiber et al. 1980; see also Discussion). Karasevich and Tatarinova (1979) reported on a slowly growing Paracoccus

Offprint requexts to. K. H. Engesser

Abbreviations: PYES, peptone yeast extract soy medium; TLC, thin layer chromatography; NIA, nitrilotriacetate; SDS-PAGE, sodium dodecylsulphate-polyacrylsulphate gel electrophoresis; FB, fluorobenzoate; DHB. 1,2-dihydro-1.2-dihydroxybenzoate: NB, nutrient broth denitrificans strain degrading 2-,3-and 4-1luorobenzoate but detailed information on the catabolic pathways were not given. To our knowledge this is the first report which describes the physiology and biochemistry of 3-fluorobenzoate degradation in greater detail

\section{Materials and methods}

Isolation of strain FLB 300 . Soil from different places of Nepal was suspended in mineral medium (Dorn et al. 1974) for enrichment with 3 -fluorobenzoate $(3 \mathrm{mM})$ as a sole source of carbon and energy. After 3 days of incubation at $30^{\circ} \mathrm{C}$ in fluted Erlenmeyer flasks on an rotary shaker $0.1 \mathrm{ml}$ of the suspension was plated on mineral medium agar plates containing 3-fluorobenzoate $(2.5 \mathrm{mM})$. One of the fastest growing colonies was picked and purified on the same agar medium. Purity was checked on nutrient agar plates.

Characterization. For taxonomic investigations the strain FLB 300 was grown in PYES medium ( $\mathrm{pH} 7.0$ ) containing $0.3 \%$ peptone from meat, $0.3 \%$ ycast extract, and $0.1 \%$ succinic acid. Cells for analysis of polyamines were harvested from exponentially growing cultures, lyophilized, extracted and analyzed according to Scherer and Kneifel (1983). The concentrations of polyamines were calculated as described by Busse and Auling (1988). Extraction and analysis of quinones, isolation of DNA, determination of GC content and sodium dodecylsulphate polyacrylamide gel electrophoresis (SDS-PAGE) followed the procedures of Auling et al. (1986). Scrological methods have been described by Auling et al. (1978). Reverse transcriptase sequencing of rRNA basically followed the method developed by Lane et al. (1985). The primer $1392-1406$ used $(2.5 \mu \mathrm{g} / \mathrm{ml})$ was a gift from Applied Biosystems.

Growth in liquid culture. Throughoul the growth experiments phosphate buffer ( $50 \mathrm{mM}, \mathrm{pH} \mathrm{7.4)}$ was used. Batch cultivation was performed in fluted Erlenmeyer flasks incubated by $30^{\circ} \mathrm{C}$ on a rotary shaker $(150 \mathrm{rpm})$. For the conditions of continuous cultivation see Knackmuss and Hellwig (1978) with the exception that the culture fluid was pumped of by means of a peristaltic pump (LKB, Bromma, Sweden).

Estimation of doubling times in continuous culture. After determination of the maximal dilution rate td was estimated. 
Due to increasing accumulation of autoxidable polyhydric phenols this state was very labile. Repeated measurements had to be done from which the mean values of td were calculated.

For preparation of cell extracts and measurement of enzyme activities with whole cells as well as in crude extracts see Pieper et al. (1988), Schmidt and Knackmuss (1980), Dorn and Knackmuss (1978) and Engesser et al. (1988). Maleylacetate reductase was determined as follows: $500 \mu \mathrm{l}$ Tris/ $/ \mathrm{HCl} 100 \mathrm{mM} ; \mathrm{pH} 7.5 ; 420 \mu \mathrm{I} \mathrm{H}_{2} \mathrm{O} ; 10 \mu \mathrm{l}$ crude extract; $20 \mu \mathrm{l} \mathrm{NADH}(10 \mathrm{mM}) ; 50 \mu \mathrm{l}$ Maleylacetate $(2 \mathrm{mM})$. The HPLC solvent system consisted, if not otherwise noted, of water/methanol $(85 / 15 \mathrm{v}, \mathrm{v})$ acidified with $\mathrm{H}_{3} \mathrm{PO}_{4}(1 \mathrm{~g} / \mathrm{l})$. The columns were of the reversed phase type (see Pieper et al. 1988). Fluoride was determined with an ion sensitive electrode (Engesser et al. 1980).

Chemicals. Substituted 3,5-cyclohexadiene-1,2-diol-1-carboxylic acids and 2-fluoro-cis,cis-muconate were gifts from W. Reineke and E. Schmidt, BUGH Wuppertal, Wuppertal, FRG with the exception of unsubstituted and 6-fluorosubstituted 3,5-cyclohexadiene-1,2-diol-1-carboxylic acid, which were prepared as previously described (Engesser et al. 1980). Highly unstable 3-fluoro-cis,cis-muconate was prepared in situ by the action of purified catechol-1,2-dioxygenase, a gift from Michael Schlömann (Univ. Stuttgart, Stuttgart, FRG), who also supplied maleylacetate. Substituted catechols were a gift from M. Hellwig (Univ. of Göttingen, Göttingen, FRG).

All other chemicals were of the highest commercially available grade.

\section{Results}

\section{Isolation of strain FLB 300}

Soil from different areas of Nepal was incubated with mineral medium and 3-fluorobenzoate as sole source of carbon and energy. Single colonies were purified on nutrient broth and checked for growth on fluorobenzoates in liquid medium. The fastest growing isolate was designated FLB300. The strain utilized benzoate, the isomeric fluorobenzoates and 4-hydroxybenzoate. After streaking on 3-hydroxybenzoate containing agar plates only few single colonies were observed. No growth could be detected with 2 -hydroxy-and 2,3-dihydroxybenzoate.

\section{Taxonomic characterization of strain FLB300}

Examination of the Gram-negative strain FLB 300 by the multiple-test system API 20 NE yielded the code 1667344 and the isolate was identified by the API profile index as Agrohacterium radiobacter with a probability of $99.9 \%$. The GC content of FLB 300 was determined as $61.9 \%$. The result would be consistent with an allocation of strain FLB300 to the genus Agrobacterium.

Chemotaxonomy has been employed for identification of Gram-negative, aerobic isolates at the genus or even lower level as an approach used alternatively to studies of the ribosomal RNA (Auling et al. 1988a; Busse et al. 1989). For grouping of any isolate within the class Prateobacteria which covers the majority of the aerobic, Gram-negative bacteria (Stackebrandt et al. 1988) combined analysis of either quinones and fatty acids (Oyaizu and Komagata 1983) or quin- ones and polyamines (Busse and Auling 1988) has been recommended. Upon TLC analysis the Gram-negative isolate FLB300 displayed a ubiquinone with 10 isoprenoid units in the side chain (Q-10) as main quinone which allowed its allocation to the alpha-subclass of Proteobucteria. Quantitative analysis of polyamines by HPLC yielded the following results (data given in $\mu$ moles/g dry weight): putrescine $=$ 5.2 , spermidine $=11.2$, sym-homospermidinc $=26.3$, and spermine $=0.3$. This pattern enabled allocation of strain FLB 300 to the alpha-2 subclass of Proteobacteria (Busse and Auling 1988).

The analysis of the $16 S$ rRNA fragment $1220-1380$ (Escherichia coli nomenclature) confirmed that FLB 300 is a member of the alpha-2 subclass of Proteobacteria. The deletion at position 1290 which is typical for members of the alpha subclass (Oyaizu, pers. commun. J. Busse, unpublished results) was detected in the $16 S$ rRNA of FLB300. The partial sequences obtained for strain FLB300, Rhizobium meliloti strain TE9 which is a nitrilotriacetate (NTA) utilizer (Egli et al. 1988), Pseudomonas aminovorans (NCIB 9039, Agrobacterium tumefaciens C58, Agrobacterium spec. HK 4 (Nobile and Deshusses 1986), and Agrohacterium radiobacter M2/1 (Oyaizu, unpublished results) displayed at least $98.75 \%$ sequence homology.

The strains found to be nearest neighbours of FLB 300 as judged by rapid sequencing of rRNA were submitted to SDS-PAGE of soluble proteins together with FLB 300 in order to detect any similarity on the subgeneric level. The protein fingerprinting (not shown) indicated a strong similarity of FLB 300 to strain HK 4. As polyclonal antibodies specific for the NTA utilizing strain TE9 (El-Banna 1989; unpublished results) were available, these were tested for cross-reactivity to FLB 300 in Ouchterlony-type double diffusions with bacterial extracts. However, only a week crossreactivity was detected.

\section{Growth in batch culture}

Strain FLB 300 was grown in succinate mineral medium as a sole source of carbon and energy. The doubling time was calculated to be $1.2 \mathrm{~h}$ at a substrate concentration of $10 \mathrm{mM}$.

Addition of benzoate to succinate $(10 \mathrm{mM})$ metabolizing cultures influenced growth. The lag phase increased from $1.2 \mathrm{~h}$ ( $2 \mathrm{mM}$ benzoate added) to $2 \mathrm{~h}(5 \mathrm{mM}), 2.5 \mathrm{~h}(7 \mathrm{mM})$ and exceeded $3.5 \mathrm{~h}$ at a benzoate concentration of $10 \mathrm{mM}$. This showed the inhibiting influence of benzoate on growing cells of strain FLB 300, an effect which was even more pronounced when fluorobenzoates were added. Therefore and due to accumulation of polyhydric phenolic compounds during metabolism of the latter all experiments with fluorobenzoates were done in continuous culture in order to keep substrate concentration low. In batch culture, logarithmic growth could only be detected with benzoate as a substrate $(\mathrm{td}=2.1 \mathrm{~h} ;[\mathrm{s}]=5 \mathrm{mM}) ;$ no constant doubling time was found for fluorobenzoate growth. In the latter case, the cultures were extremely unstable showing a more linear correlation of decrease of substrate concentration and increase in OD. Furthermore a brownish-black coloration was observed indicating intoxication of the cells due to accumulation of fluorosubstituted catechols.

\section{Growth in continuous culture}

The steady state optical densities for 2-fluoro-, 3-fluoroand 4-fluorobenzoate as substrate (influent concentration 
Table 1. Relative amounts of fluoride and 2-fluoromuconate after growth of FLB 300 with fluorobenzoates. Cells were grown in continuous culture as described in Materials and methods. For $3 \mathrm{FB}$ as the most interesting substrate results of three independent experiments are shown. For determination of fluorobenzoates (FB) at the beginning $\left(t_{0}\right)$ or the end of the experiments $\left(t_{1}\right)$ and 2 fluoromuconate (FM) see text; determination of fluoride $\left(\mathrm{F}^{-}\right)$was done as described in Materials and methods

\begin{tabular}{|c|c|c|c|c|c|}
\hline & \multicolumn{5}{|c|}{$\begin{array}{l}\text { Compounds and ions }[\mathrm{mM}] \\
\text { after growth with }\end{array}$} \\
\hline & $2 \mathrm{FB}$ & $3 F B$ & & & $4 \mathrm{FB}$ \\
\hline $\begin{array}{l}\text { Growth substrate } \\
\text { - influent } \\
\text { - culture fluid }\end{array}$ & $\begin{array}{r}7.3 \\
\leq 0.1\end{array}$ & $\begin{array}{r}4.8 \\
\leq 0.1\end{array}$ & $\begin{array}{r}4.9 \\
\leq 0.1\end{array}$ & $\begin{array}{r}4.0 \\
\leq 0.1\end{array}$ & $\begin{aligned} & 5.85 \\
\leq & 0.1\end{aligned}$ \\
\hline $\begin{array}{l}\text { Fluoride } \\
\text { - influent } \\
\text { - culture fluid }\end{array}$ & $\begin{array}{r}\leq 0.1 \\
5.8\end{array}$ & $\begin{array}{r}\leq 0.1 \\
4.2\end{array}$ & $\begin{array}{r}\leq 0.1 \\
4.4\end{array}$ & $\begin{array}{r}\leq 0.1 \\
3.1\end{array}$ & $\begin{array}{r}\leq 0.1 \\
4.0\end{array}$ \\
\hline $\begin{array}{l}\text { 2-Eluoromucunate } \\
\text { - culture fluid }\end{array}$ & 1.0 & 0.4 & 0.6 & 0.6 & - \\
\hline$\frac{\left[\mathrm{F}^{-}\right] \cdot 100}{\left[\mathrm{~F}^{-}\right]+[\mathrm{FM}]}$ & 85 & 91 & 88 & 84 & - \\
\hline$\frac{\left[\mathrm{F}^{-}\right]+[\mathrm{FM}] \cdot 100}{[\mathrm{FB}] t_{0}-[\mathrm{FB}] t_{1}}$ & 97 & 96 & 102 & 93 & 68 \\
\hline
\end{tabular}

Table 2. Turnover rates of benzoates by FLB 300 cells after growth with benzoates. Relative turnover rates of cells of FLB 300 were determined with IIPLC (see Engesser et al. 1988) using an eluent mixture of water/methanol $(80 / 20 \mathrm{v} / \mathrm{v})$. Rates were calculated taking the value of benzoate as $100 \%$

\begin{tabular}{lcccc}
\hline $\begin{array}{l}\text { Test } \\
\text { substrate }\end{array}$ & \multicolumn{4}{l}{$\begin{array}{l}\text { Relative turnover rates } \\
\text { of benzoates after growth with }\end{array}$} \\
\cline { 2 - 5 } & Benzoate & $\begin{array}{l}\text { 2-Fluoro- } \\
\text { benzoatc }\end{array}$ & $\begin{array}{l}\text { 3-Fluoro- } \\
\text { benzoate }\end{array}$ & $\begin{array}{l}\text { 4-Fluoro- } \\
\text { benzoate }\end{array}$ \\
\hline Benzoate & 100 & 100 & 100 & 100 \\
2-fluoro- & 15 & 60 & 60 & 10 \\
3-fluoro- & 35 & 90 & 80 & 60 \\
4-fluoro- & 55 & 75 & 100 & 60 \\
3-chloro- & 25 & 40 & 55 & 35 \\
4-chloro- & 15 & 15 & 35 & 20 \\
2-methyl- & $\geq 5$ & 10 & 10 & 5 \\
3-methyl- & 20 & 30 & 80 & 35 \\
4-methyl- & 20 & 45 & 60 & 30 \\
3,5-dimethyl- & $\geq 5$ & $\geq 5$ & 10 & $\geq 5$ \\
\hline
\end{tabular}

$10 \mathrm{mM}$ ) werc measured to be $1.2,1.35$ and 2.1 respectively. The corresponding dilution rates were $\mathrm{D}=0.053 \mathrm{~h}^{-1}$, $0.063 \mathrm{~h}^{-1}$ and $0.0385 \mathrm{~h}^{-1}$ respectively. When benzoate was the substrate $(10 \mathrm{mM}$; estimated only in batch culture) a value of $O D=2.8$ was found. When cells of a 3 fluorobenzoate degrading continuous culture were plated on $\mathrm{NB}$, benzoate or fluorobenzoate containing agar plates, cell numbers were calculated in all cases to be approximately the same $\left(2.5 \cdot 10^{9}\right.$ cells $\left./ \mathrm{ml}\right)$. This showed that all 3fluorobenzoate utilizing cells had the capacity to grow with benzoate, 2-fluoro- and 4-fluorobenzoate.

The doubling times in continuous cultures were $13 \mathrm{~h}$ (3FB), $11 \mathrm{~h}(4 \mathrm{FB})$ and $18 \mathrm{~h}(2 \mathrm{FB})$, calculated at the dilution
Table 3. Rates of oxygen uptake by 3-fluorobenzoate grown cells of strain FLB300. Cells were grown in continuous culture with 3fluorobenzoate as sole carbon source $(O D=0.7)$. After concentration to $O D_{546 \mathrm{~mm}}=9$ in phosphate buffer $\mathrm{pH} 7.4 .1 \mathrm{ml}$ of the cell suspension was diluted in $3 \mathrm{ml}$ phosphate buffer for oxygen measurements adjusting a final $\mathrm{OD}=2.25$. Substrate were added to final concentrations of $0.25 \mathrm{mM}$ (catechols) and $2.5 \mathrm{mM}$ (acids) Activities are expressed as nmoles $\mathrm{O}_{2} \cdot \mathrm{min}^{-1} \cdot \mathrm{ml}^{-1}$ cell suspension. Values in parenthesis refer to 3-fluorobenzoatc $=100 \%$

\begin{tabular}{lc}
\hline Substrate & Oxygen uptake \\
\hline Catechol $^{\text {3-Fluorobenzoate }}$ & $188(750)$ \\
3-Fluorocatechol & $25(100)$ \\
4-Fluorocatcchol & $5(20)$ \\
2-Hydroxybenzoate & $45(180)$ \\
3-Hydroxybenzoate & $5(20)$ \\
4-Hydroxybenzoate & $<2(<10)$ \\
3-Chlorobenroatc & $3(10)$ \\
3,4-Dihydroxybenzoate & $18(70)$ \\
2,5-Dihydroxybenzoate & $5(20)$ \\
2,3-Dihydroxybenzoate & $<2(<10)$ \\
\hline
\end{tabular}

a For comparative purposes the values for benzoate. 2 -fluoro- and 4-fluorobenzoate are given as 19,3 and $16 \mathrm{nmoles} \cdot \mathrm{min}^{-1} \cdot \mathrm{ml}^{-1}$ cell suspension respectively

rates mentioned above. The concentration of the respective substrate in the reservoir was $10 \mathrm{mM}$. The sensitivity of strain FLB300 even in continuous culture with respect to high concentrations of fluorobenzoates was demonstrated after lowering the concentration of 2 FB (i.e. from $10 \mathrm{mM}$ to $5 \mathrm{mM}$ ). The corresponding doubling time then was found to be $11 \mathrm{~h}$ instead of $18 \mathrm{~h}$.

\section{Excretion of metabolites}

During growth of FLB 300 with 2- and 3-1luorobenzoate in continuous culture fluoride and a polar metabolite were excreted into the growth medium. The latter was identilied by comparing HPLC retention volumina ( $\mathrm{Rv}$ ) and UV spectra to be 2-fluoro-cis, cis-muconate ( $\mathrm{Rv}=3.25 \mathrm{ml}$ compared to $3.37 \mathrm{ml}$ for authentic 2-fluoro-cis,cis-muconate; $\lambda_{\max }$ in both cascs $264 \mathrm{~nm} ; \lambda_{\min }$ at $212 \mathrm{~nm}$ ). Fluorosubstituted analogues of 1,2-dihydro-1,2-dihydroxybenzoate (3,5-cyclohexadiene-1,2-diol-1-carboxylic acid) could be ruled out by comparison with authentic compounds (HPLC data not shown).

\section{Stoichiometry of accumulated metabotites}

During steady state growth on fluorobenzoates in continuous culture the relative amounts of fluoride and 2-fluoromuconate formed were determined (Table 1). With the exception of the 4-fluorobenzoate culture, the sum of excreted metabolites nearly equalled the amount of fluorobenzoates transformed. 2-Fluoromuconate is a dead end product in this strain as no turnover of this compound can be observed neither in crude extracts nor with whole cells.

\section{Enzymatic activities in whole cells}

As enzyme activity for benzoate and fluorobenzoates could not be detected in crude extracts, turnover of these substrates 
Table 4. Enzymes in cell extracts of strain FLB 300. The absolute activities are given in parentheses as U/g protein. The relative activities are referred to the respective unsubstituted parent compounds taken to be $100 \%$. For determination of all enzyme expect maleylacetate reductase see Engesser et al. (1988), Schmidt and Knackmuss (1980) and Dom and Knackmuss (1978). Maicylacetate reductase was determined as described in Materials and methods. No bydrolizing activity was found for the cis- and irans-isomere of 4-carboxymethylenebut-2-en-4-olide

\begin{tabular}{|c|c|c|c|c|}
\hline \multirow[t]{2}{*}{ Enzyme/Substrate } & \multirow[t]{2}{*}{ Benzoate } & \multicolumn{3}{|l|}{ Growth substrate } \\
\hline & & 2-Fluorubenzoate & 3-Fluorobenzoate & 4-Fluorobetizoate \\
\hline \multicolumn{5}{|l|}{ DHB Dehydrogenase } \\
\hline $\mathrm{DHB}^{a}$ & $100(4,170)$ & $100(6,915)$ & $100(3,000)$ & $100(2,825)$ \\
\hline 3-Fluoro-DHB & $86(3,580)$ & n.d. & $72(2,150)$ & n.d. \\
\hline 4-Fluoro-DHB & $64(2,660)$ & $90(6,225)$ & $90(2,700)$ & $94(2,650)$ \\
\hline 5-Fluoro-DHB & $9(380)$ & $6(415)$ & $9(270)$ & $13(355)$ \\
\hline 6-Fluoro-DHB & $82(3,410)$ & $75(5,190)$ & $90(2,700)$ & $108(3,060)$ \\
\hline \multicolumn{5}{|l|}{ Catechol 1,2-Dioxygenase } \\
\hline Catechol & $100(1,340)$ & $100(700)$ & $100(860)$ & $100(585)$ \\
\hline 3-Fluorocatechol & $1(19)$ & $7(50)$ & $9(1)$ & $2(10)$ \\
\hline 4-Fluorocatechol & $11(150)$ & $21(145)$ & $12(105)$ & $16(55)$ \\
\hline 3-Chlorocatechol & $1(14)$ & $4(30)$ & $1(6)$ & $3(15)$ \\
\hline 4. Chlorocatechol & $2(30)$ & $6(40)$ & $3(24)$ & $3(15)$ \\
\hline 3-Methyicatechol & $12(160)$ & $8(55)$ & $15(130)$ & $8(45)$ \\
\hline 4-Methylcatechol & $22(300)$ & $19(131)$ & $16(140)$ & $11(65)$ \\
\hline \multicolumn{5}{|l|}{ Muconate cycloisomerase } \\
\hline 2-Fluoro-cis,cis-muconate & $1(8)$ & $1(6)$ & $\leq 1(\leq 3)$ & $\leq 1(\leq 3)$ \\
\hline 3-Fluoro-cis,cis-muconate & n.d. & $25(160)$ & $21(50)$ & $33(70)$ \\
\hline \multicolumn{5}{|l|}{ Maleylacetate reductase } \\
\hline Maleylacetate & $<3$ & $<3$ & 230 & 295 \\
\hline
\end{tabular}

2 DHB: 1,2-Dihydro-1,2-dihydroxybenzoate

b n.d. not determined

was determined with whole cells (Table 2). The rates of turnover of the organic substrates were estimated using HPLC because oxygen uptake rates were falsified by other $\mathrm{O}_{2}$ consuming reactions like ring clcavage of catechols.

Oxygen uptake rates with whole cells were measured in order to investigate the relative rates of metabolism of catechols and benzoates respectively (Table 3 ). High turnover rates for catechols and low to very low rates for other potential ring cleavage substrates suggested catechols to be intermediates of 3-fluorobenzoate degradation.

\section{Enzymatic activities in crude extracts}

After growth of FLB300 with benzoate or the isomeric fluorobenzoates respectively activities of 1,2-dihydro-1,2dihydroxybenzoate dehydrogenase (DHB-dehydrogenase), catechol-1,2-dioxygenase, muconate cycloisomerase, 4-carboxymethylenebut-2-en-4-olide hydrolase and maleylacetate reductase were determined (Table 4). In contrast to an enzyme preparation of 3-chlorobenzoate grown Psezdomonas $s p$. B 13 neither the cis-nor the trans-isomere of 4-carboxymethylenebut-2-en-4-olide was bydrolyzed.

\section{Discussion}

The productive metabolism of monofluorobenzoates by bacteria has been the subject of many investigations. Accordingly, also the cometabolism of these xenobiotics by soil bactcria was followed and shown to proceed via the normal routes of benzoate degradation with fluorinated catechols as intermediates (Fig. 1).

These were detected in the growth medium (Hughes 1964; Clarke et al. 1975; Horvath and Flathman 1976) which is explained by the fact that the fluorine substituent being only slightly different in size from hydrogen can exert a strong polarizing effect due to its pronounced electronegative character. Accordingly fluorinated analogues can be metabolized to a metabolic stage at which the electronic influence of the fluorine substituent prevents or at least strongly retards further metabolism (Engesser et al. 1988). Catechol 1,2-dioxygenases from normal benzoate pathways have becn reported to exhibit considerably low activity with 4-fluorocatechol compared to catechol and almost no turnover activity with 3-fluorocatechol (Dorn and Knackmuss 1978; Engesser et al. 1988). This inertness of 3-fluorocatechol towards ortho-cleavage enzymes is one of the reasons why benzoate degrading bacteria normally are not able to grow with 2- and 3-fluorobenzoate. In addition the intermediarily formed 3-fluorocatechol tends to accumulate and by autoxidation intoxicates the cells (Schreiber et al. 1980).

In the case of 2-fluorobenzoate, Pseudomonas sp. B13 after a long adaptation period utilized this substrate as a carbon source. From Fig. 1 one can deduce that the regioselectivity of dioxygenation of 2-fluorobenzoate determines the ratio of the two products formed: While 1,2dioxygenation yields an unstable geminal fluoro-hydroxy substituted compound which chemically dccomposes to inorganic fluoride and well metabolizable catechol, the 1,6dioxygenation leads to toxic 3 -fluorocatechol. Thus a change 


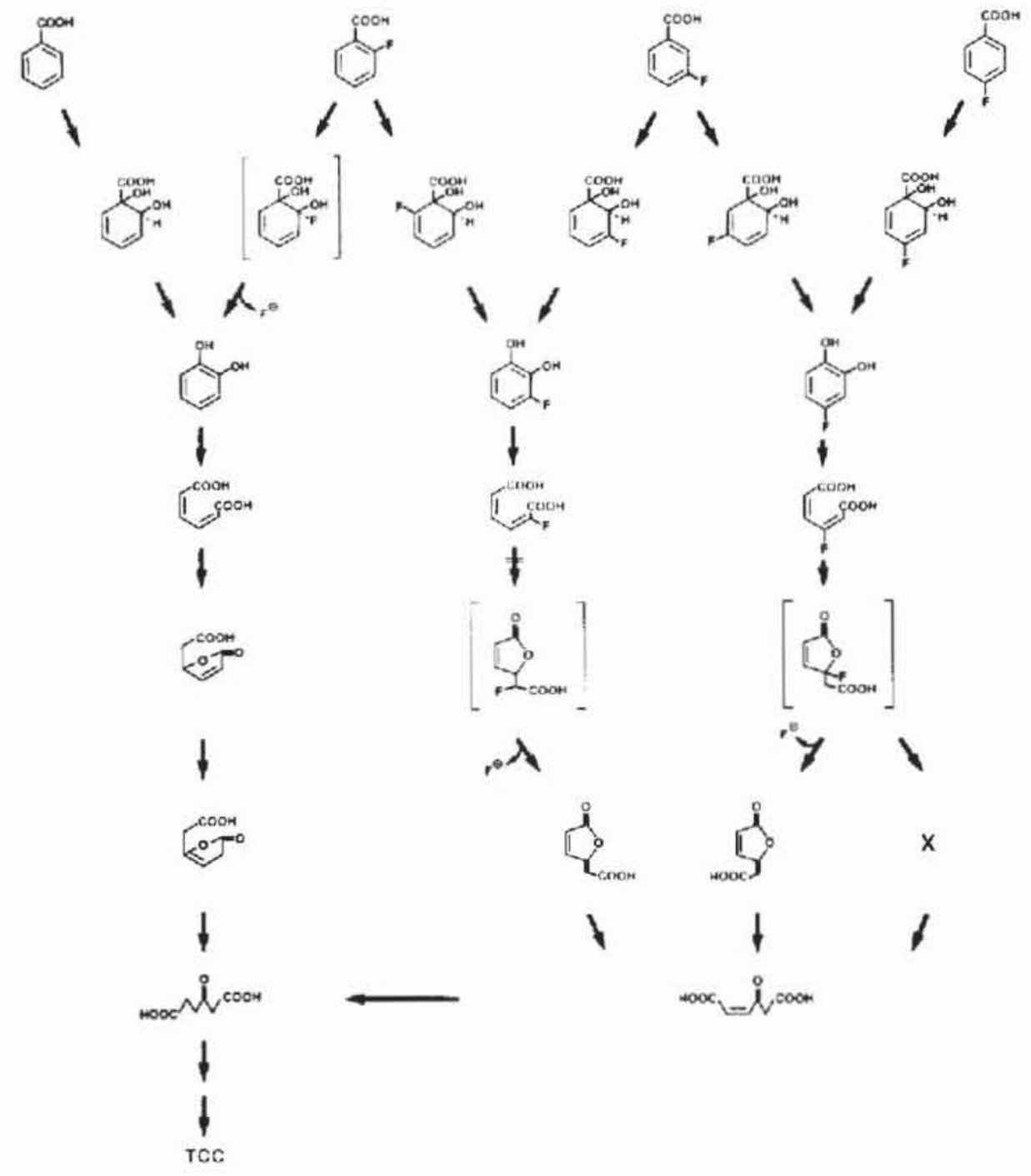

Fig. 1

Pathways of degradation of benzoate and fluorosubstituted benzoates in bacteria (compounds are listed from the left to the right): 1st row: benzoate, 2-, 3- and 4-fluorobenzoate; 2 nd row: DHB (1,2-dihydro1,2-dihydroxybenzoate) and fluorinated derivatives; 3 rd row: catechol, 3- and 4-fluorocatcchol; 4th row: cis,cis-muconate, 2 - and 3-fluoromuconate; 5 th row: 4-carboxymethylbul-2-en-4-olide (muconolactone) and fluorosubstitutal derivatives; 6 th row: 4-carboxymethylbut-3-en-4-olide and two stereoisomers of 4-carboxymethylenebut-2-en-4-olide; 7 th row: 3 -oxoadipate and maleylacetate

in regioselectivity from unfavourable 1,6-dioxygenation to 1,2-attack enabled strain B13 to utilize 2-fluorobenzoate as a carbon source (Engesser et al. 1980). FLB300 seems to have followed the same adaptive strategy.

Degradation of 4-fluorobenzoate has been described earlier (Harper and Blakley 1971 c; Schreiber et al. 1980). In this case only 4-fluorocatechol is produced, which was suggested to be metabolized via 3-fluoro-cis,cis-muconate (see Table 4) and 4-carboxymethyl-4-fluorobut-2-en-4-olide as intermediates. The latter, after elimination of $\mathrm{HF}$, could lead to formation of 4-carboxymethylenebut-2-en-4-olide (Schreiber et al. 1980). A hydrolase then would produce maleylacetate which after reduction to 3-oxoadipate is degraded via reactions of the normal 3-oxoadipate pathway.

Alternatively a direct ring reaction was proposed opening the lactone ring directly (Harper and Blakley 1971 c) to a product carrying a chemically unstable gem fluorohydroxysubstituted carbon atom. After spontaneous release of HF maleylacetate could be formed, which could be metabolized as described above.

In FLB300 4-fluorobenzoate seems to be degraded via the latter pathway. Accordingly no activity for both stereoisomeres of 4-carboxymethylenebut-2-en-4-olide was detectable in cells grown on fluorobenzoates although a possible instability of this enzyme in crude extracts could not be ruled out. The next enzyme of the pathway, maleylacetate reductase, was specifically induced in 4- and 3-fluorobenzoate grown cells but not in benzoate and 2-fluorobenzoate grown cells.

The most interesting feature of FLB300, however, is its ability to utilize 3-fluorobenzoate as a carbon source. From Table 3 it is clear that neither 3-hydroxybenzoate nor protocatcchuate can be pathway intermediates. This holds also for 2,3-dihydroxybenzoate which cannot be utilized as a carbon source although it is oxygenated at a relatively high rate (Table 3). Instead, fluorosubstituted catechols must be produced from 3-fluorobenzoate. As there is no metabolism of 2-fluoromuconate in crude extracts of 3-fluorobenzoate grown FLB300, ring cleavage of 3-fluorocatechol is unproductive. Therefore, as in the case of 4-fluorobenzoate degradation, only ortho-cleavage of 4-fluorocatechol can account for growth on 3-fluorobenzoate. Furthermore, since 3fluorocatechol is only insufficiently cleaved to untoxic 2fluoromuconate and tends to intoxicate the cells, the regioselectivity of 3-fluorobenzoate dioxygenation (1,2- or 1,6position) should strongly influence the growth rate with 3 fluorobenzoate.

Table 5 shows that FLB300 is unique in converting the major part of 3-fluorobenzoate to 4-fluorocatechol thereby allowing convergence with the $4 \mathrm{FB}$ pathway. Nevertheless, 
Table 5. Regioselectivity of benzoate dioxygenases from different bacterial sources. The regioselectivity of the benzoate dioxygenases was calculated from the ratios of concentrations of fluoride and 2-fluoromuconate after transformation of 3-fluorobenzoate. For determination of these metabolites see Materials and methods. Fluoride was used as an indicator for the 4-fluorocatechol branch (i.e. 1,6-dioxygenation), 2-fluoromuconate for the 3-fluorocatechol branch (1,2-dioxygenation)

\begin{tabular}{|c|c|c|c|}
\hline \multirow[t]{2}{*}{ Organism } & \multicolumn{2}{|c|}{$\begin{array}{l}\text { Relative velocities of dioxygenation } \\
\text { of 3-flunrobenzoate in }\end{array}$} & \multirow[t]{2}{*}{$\begin{array}{l}\text { Literature } \\
\text { reference }\end{array}$} \\
\hline & $\begin{array}{l}\text { 1,2-position } \\
\text { (3-fluorocatechol } \\
\text { branch) }\end{array}$ & $\begin{array}{l}\text { 1,6-position } \\
\text { (4-fluorocatechol } \\
\text { branch) }\end{array}$ & \\
\hline FLB 300 & 14 & 86 & this study \\
\hline Alcaligenes eutrophus B9 & 50 & 50 & Engesser et al. 1980 \\
\hline Pseudomonas sp. B13 & 87 & 13 & Schmidt and Knackmuss 1984 \\
\hline Alcaligenes sp. A 7-2 & 87 & 13 & Schmidt and Knackmuss 1984 \\
\hline Acinetobacter calcoaceticus & 66 & 34 & Clarke et al. 1975 \\
\hline
\end{tabular}

some 3-fluorocatechol is produced which intoxicates the cells and probably is responsible for the rather low growth rate on 3-fluorobenzoate. This problem of cleavage of fluorocatechols could be circumvented by employing highly specialized chlorocatechol-cleaving pyrocatechases. These enzymes are known to be involved in degradation of chloroaromatics and show at least moderate relative rates for cleavage of 3-fluorocatechol and excellent rates for turnover of 4-fluorocatechol. As in most cases the enzymes for degradation of chloroaromatics are not induced by fluorine substituted aromatics, constitutive mutants are of spccia] interest in order to achieve an improved degradation of fluorinated aromatics. Such experiments are currently undertaken with Aicaligenes eutrophus JMP 134-1 a constitutive mulant of its 2,4-D (2,4-dichlorophenoxyacetic acid) degrading wildtype (Pieper et al. 1985, 1989).

The results of the taxonomic investigations presented here clearly exclude strain FLB 300 from a phylogenetically defined genus Pseudomonas (De Vos and De Ley 1983; Woese et al. 1984a). Chemotaxonomic and rRNA data suggest allocation of FLB 300 to the alpha-2 subclass of Proteobacteria (Woese et al. 1984b; Stackebrandt et al. 1988). Although a phylogenetical relationship of FLB300 to the Agrobacterium-Rhizobium branch (De Ley et al. 1987) is indicated, designation by API $20 \mathrm{NE}$ as Agrobacterium radiobacter cannot be accepted due to the polyamine pattern found in strain FLB300: Whereas only traces of symhomospermidine are to be expected in Agrobacterium radiobacter M2/1 (Busse and Auling 1988), this triamine is the main polyamine in strain FLB 300, Agrobacterium sp. HK 4, strain TE9 and $P$. aminovorans NCIB 9093 - all of them having a very similar $16 \mathrm{~S}$ rRNA fragment. We do not consider it prudent to make formal taxonomic proposals for isolate FLB300 at present, because further studies for comparison with the phylogenetically related strains emerging are necessary. Facing a similar situation with $P$. aminovorans, Green and Gillis (1989) came to the same decision of avoiding a premature classification.

Acknowledyement. For skilled technical assistance we thank M. Bachmann and J. Reupke. The help of M. Schlömann with determining the dicnelactone hydrolase and maleylacetate reductase as well as critical reading of the manuscript is gratefully acknowledged. For analysis of $16 \mathrm{~s}$-rRNA fragments we wish to thank $\mathrm{H}$. Oyaizu. This work was supported by grants from the Bundesministerium für Forschung und Technologie and the Gcrman collection of Microorganisms and Cell Cultures Ltd., (DSM), Braun- schweig, FRG. A short-term fellowship to H.-J. Busse from the Deutscher Akademischer Auslandsdienst (DAAD), Bonn, FRG, is gratefully acknowledged.

\section{References}

Auling G, Reh M, Lee CM, Schlegel HG (1978) Pseudomonas pseudoflava, a new species of hydrogen-oxidizing bacteria: Its differentiation from Pseudomonas flava and other yellow-pigmented, Gram-negative, hydrogen-oxidizing species. Int J Syst Bacteriol 28:82-95

Auling G, Probst A. Kroppenstedt RM (1986) Chemo- and molecular taxonomy of $\mathrm{D}(-)$-tartrate-utilizing pseudomonads. Syst Appl Microbiol 8:114-120

Auling G, Busse J, Hahn M, Hennecke H, Kroppenstedt RM, Probst A, Stackebrandt E (1988) Phylogenetic heterogeneity and chemotaxonomic properties of certain Gram-negative carboxydobacteria. Syst Appl Microbiol 10:264-272

Banks RE (1979) Organo-fluorine chemicals and their industrial applications. Chichester: Ellis Harwood Ltd.

Banks RE (1982) Preparation, properties and industrial applications of organo-fluorine compounds. Chichester: Ellis Harwood Ltd.

Busse J, Auling G (1988) Pulyamine paticrn as a chemotaxonomic marker within the Proteobacteria. Syst Appl Microbiol 11:18

Busse HJ, El-Banna T, Auling G (1989) Evaluation of different approaches for identification of xenobiotic-degrading pseudomonads. Appl Environm Microbiol 55:(in press)

Clarke KF, Kallely AG, Livingstone A, Fewson CA (1975) Metabolism of monofluorobenzoates by Acinetobacter calcoaceticus NCIB 8250. Formation of monofluorocatechols. Biochim Biophys Acta 404:169-179

Dc Ley J, Mannheim W, Segers P, Lievens M, Denijn A, Vanhoucke M, Gillis M (1987) Ribosomal ribonucleic acid cistron similaritics and taxonomic neighbourhood of Brucella and CDC group Vd. Int Syst Bacteriol 37:35-42

De Vos P, De Ley J (1983) Intra- and intergeneric similarities of Pseudomonas and Xanthomonas ribosomal ribonucleic acid cistrons. Int J Syst Bact 33:487-509

Dorn E, Hellwig M, Reincke W, Knackmuss H-J (1974) Isolation and characterization of a 3-chlorobenzoate degrading pseudomonad. Arch Microbiol 99:61-70

Dorn E, Knackmuss H-J (1978) Chemical structure and biodegradability of halogenated aromatic compounds. Biochem J $174: 85-94$

Egli T, Weilenmann HU, El-Banna T, Auling G (1988) Gramnegative, aerobic, nitrilotriacetate-utilizing bacteria from wastewater and soil. System Appl Microbiol 10:297-305

El-Banna T (1989) Characterization of some unclassified Pscudomonas species. $\mathrm{PhD}$ Thesis. Tanta University, Tanta. Egypt 
Engesser KH, Schulte P (1989) Degradation of 2-bromo-, 2-chloroand 2-fluorobenzoate by Pseudomonas putida CLB 250. FEMS Lett $60: 143-148$

Engesser KH, Schmidt E, Knackmuss H-J (1980) Adaptation of Alcaligenes eutrophus $\mathrm{B} 9$ and Pseudomonas sp. B13 to 2fluorobenzoate as growth substrate. Appl Environm Microbiol $39: 68-73$

Engesser KH, Cain RB, Knackmuss K-J (1988) Bacterial metabolism of side chain fluorinated aromatics: cometabolism of 3trifluoromethyl (TFM) benzoate by Pseudomonas putido (arvilla) mt-2 and Rhodococcus rubropertinctus N657. Arch Microbiol 149:188-197

Filler R (1979) Biochemistry involving carbon-fluorine compounds. American Chem Symposium, Series No. 28, Washington

Gajewski RP, Thumpson GD, Chio EH (1988) Perfluorinated alkyl carbuxyanilides: A ncw class of soil insecticide. J Agr Food Chem 36(1): $174-177$

Green PN, Gillis M (1989) Classification of Pseudomonas aminovorans and some related methylated amine utilizing bacteria. J Gen Microbiol 135:2071-2076

Harper DB, Blakley ER (1971a) The metabolism of pfluorophenylacetic acid by a Pseudomonas sp. I. The degradative pathway. Can J Microbiol 17:635-644

Harper DB, Blakley ER (1971 b) The metabolism of p-fluorophenylacetic acid by a Pseudomonas sp. II. Isolation and identification of intermediates. Can $\mathrm{J}$ Microbjol 17:645-650

Harper DB, Blakley ER (1971 c) The metabolism of p-fluorobenzoic acid by a Pseudemonas sp. Can J Microbiol 17:1015-1023

Horvath RS, Flathman P (1976) Co-metabolism of fluorobenzoates by natural microbial populations. Appl Environm Microbiol $31: 889-891$

Hug M, Engesser KH, Knackmuss H-J (1988) Bacterial metabolism of ortho-substituted halobenzoates. Abstr Meet Soc Gen Microbiol P29, Southampton, p 21

Hughes DE (1964) The metabolism of halogen substituted benzoic acids by $P$ seudomonas fluorescens. Biochem J 96:181-188

Karasevich YN, Tatarinova NY (1979) Utilization of monofluorobenzoic acids by bacteria Paracoccus denitrificans. Mikrobiologiya 48:980-984

Karasevich YN, Zaitsev GM (1984) Utilization of 4-chlorobenzoic and 2,4-dichlorobenzoic acids by a mixed culture of microorganisms. Mikrobiologiya $53: 374-380$

Knackmuss H-J, Hellwig M (1978) Utilization and cooxidation of chlorinated phenols by Pseudomonas sp. B13. Arch Microbiol $117: 1-7$

Lane DJ, Pace B, Olsen GJ, Stahl DA, Sogin ML, Pace NR (1985) Rapid determination of $16 \mathrm{~S}$ ribosomal RNA sequences for phylogenetic analyscs. Proc Nat Acad Sci USA 82:6955-6959
Nobile S, Deshusses J (1986) Transport of -butyrobetaine in an Agrobacterizm species isolated from soil. J Bacteriol 168: 780784

Oyaizu H, Komagata K (1983) Grouping of Pseudomonas species on the basis of cellular fatty acid composition and the quinone system with special reference to the existence of 3-hydroxy fatty acids. J Gen Appl Microbiol 29:17-40

Pieper DH, Engesser K.H, Don RH, Timmis KN, Knackmuss HJ (1985) Modified ortho-cleavage pathway in Alcaligenes eutrophus JMP134 for the degradation of 4-methylcatechol. FEMS Microbiol Lett 29:63-67

Pieper DH, Reineke W, Engesser KH, Knackmuss K-J (1988) Metabolism of 2,4-dichlorophenoxyacetic acid, 4-chloro-2methylphenoxyacetic acid and 2-methylphenoxyacetic acid by Alcaligenes euthrophus JMP 134. Arch Microbiol 150:95-102

Pieper DH, Engesser KH, Knackmuss H-J (1989) Regulation of catabolic pathways of phenoxyacetic acids and phenols in Alcaligenes eutrophus JMP134. Arch Microbiol 151:365-371

Scherer F, Kneifel H (1983) Distribution of polyamines in methanogenic bacteria. J Bacteriol 154:1315-1322

Schmidt E, Knackmuss H-J (1980) Chemical structure and biodegradability of halogenated aromatic compounds. Biochem J $192: 339-347$

Schmidt E, Knackmus H-J (1984) Production of cis, cis-muconate from benzoate and 2-fluoro-cis,cis-muconate from 3-fluorobenzoate by 3 -chlorobenzoate degrading bacteria. Appl Microbiol Biotechnol 20:351-355

Schreiber A, Hellwig M, Dorn E, Reineke W, Knackmuss H-J (1980) Critical reactions in fluorobenzoic acid degradation by Pseudomonas sp. B13. Appl Environ Microbiol 39:58-67

Stackebrandt E, Murray RGE, Trüper HG (1988) Proteobacteria classis nov., a name for the phylogenetic taxon including the "purple bacteria and their relatives". Int J Syst Bacteriol $38: 321-325$

Welch JT (1987) Advanees in the preparation of biologically active organofluorine compounds. Tetrahedron 43:3123-3197

Woese CR, Blanz P, Hahn CM (1984a) What isn't a pseudomonad: the importance of nomenclature in bacterial classification. System Appl Microbiol 5:179-195

Wocse CR, Stackebrandt E, Weisburg WG, Paster BJ, Madigan MT, Fowler VJ, Hahn CM, Blanz P, Gupta R, Nealson KH Fox GE (1984b) The phylogeny of purple bacteria: The alpha subdivision. System Appl Microbiol 5:315-326

Received July 18, 1989/Accepted September 16, 1989 